\title{
The Relationship Between Academics' Dark Triad Traits and Their Organizational Commitment in Physical Education and Sport
}

\author{
Mustafa Yasar Sahin ${ }^{1} \&$ Sermin Agralı Ermis ${ }^{2}$ \\ ${ }^{1}$ Faculty of Sports Sciences, University of Gazi, Ankara, Turkey \\ ${ }^{2}$ Department of Physical Education and Sport, Graduate School of Health Sciences, University of Gazi, Ankara, \\ Turkey \\ Correspondence: Sermin Agralı Ermis, Department of Physical Education and Sport, Graduate School of Health \\ Sciences, University of Gazi, Ankara, Turkey. E-mail: sermin.agrali@gmail.com
}

Received: May 17, 2020

Accepted: June 30, $2020 \quad$ Online Published: August 26, 2020

doi:10.5539/ies.v13n9p75

URL: https://doi.org/10.5539/ies.v13n9p75

\begin{abstract}
The results of the recent studies on "dark triad" have caused this concept to become popular among the educational sciences. As the importance of these personality traits comes from the possibility of having an impact on students' learning. Many researchers believe that teachers 'personality traits may affect students' learning processes in the future. So the main aim of this research is to examine the relationship between the dark triad traits of the academics and the organizational commitment dimensions. In the study conducted in the relational survey model, the Dark Triad Traits Scale developed by Paulhus \& Williams (2002) and the Organizational Commitment Scale developed by Allen \& Meyer (1990) were used as data collection tools. The sample of the research consists of 372 academics determined by random method. In the analysis of the data obtained from the scales, Pearson correlation coefficient was calculated to determine the level of relationship. As a result of the research, while a very low inverse relationship was determined between the emotional commitment of academics and personality traits of Machiavellianism and psychopathy, a moderate direct relationship was found between continuance commitment and the personality traits of Machiavellianism and psychopathy.
\end{abstract}

Keywords: academics, dark triad, organizational commitment, physical education and sport

\section{Introduction}

In management science research, the concept of personality is generally examined within the scope of social psychology and organizational psychology. In the organizational context, studies on personality are mainly carried out within the scope of normal personality traits. As a result of this, the effects of characteristics related to different aspects of personality on organizational behaviour and organizational performance were ignored.

In this regard, studies on the negative aspects of personality traits have increased in different fields of science. As one of these studies, we face the concept of "dark triad" which includes subclinical (non-clinical) narcissism, Machiavellianism and subclinical psychopathy, which has been referred to as "Dark Side of Personality" recently and brought to the literature by Paulhus and Williams (2002).

Thus, the recent studies show that on dark triad in the field of management science have also focused on its relationship with various organizational behaviours such as organizational commitment and organizational exclusion.

One of the effective situations in starting the examination of the dark side of personality is the negative effects of this type of behaviour on the organizational environment. As a result of the oppressive, humiliating and selfish attitudes of individuals within the organization, the business environment can become unbearable. Such attitudes and behaviours may lead in the individual to not taking responsibilities and avoiding them, weakening sense of belonging, decreased productivity, and leaving the job in the long run.

Based on this, it is important to determine these characteristics of academics, who can affect society and the individual in every aspect, positively or negatively. It is anticipated that the investigation of the effect of these dark triad traits on organizational commitment will also support the related literature.

The aim of this study is to examine the relationship between academics' dark triad traits and organizational 
commitment dimensions.

\subsection{Dark Triad}

While the bright side of the personality expresses the quality of the interaction levels of the people in their social environment with positive adjectives, the dark side of the personality refers to the personality traits that are considered to cause negative results in terms of individuals and organizations that have attitudes that are not welcomed by the environment (Judge \& LePine, 2007, Jonason et al., 2015).

In the related literature, these non-clinical but aggressive personality traits are referred to as "Dark triad". The dark triad contains Machiavellianism, narcissism and psychopathy (Paulhus \& Williams, 2002). Machiavellianism, in its simplest form, is explained by the fact that the individual sees every way permissible, displaying manipulative behaviour through adulation and deception in interpersonal communication in order to achieve his/her own interests (Fehr, Samson, \& Paulhus, 1992). In the most general sense, Narcissism means having traits such as excessive self-love, high desire to be liked, and lack of empathy (Geçtan, 2010). Psychopathy, on the other hand, is used to describe individuals who have traits such as lack of moral values, no regrets and behaving uncontrollably (Arrigo \& Shipley, 2001).

Although their origins are different, all three members of the dark side of personality show socially undesirable behaviour, grandiose, emotional coldness, aggression and manipulative behavior (Paulhus \& Williams, 2002).

Jonason, Slomski, and Partyka (2012) stated that as their manipulation tactics, Machiavelists use mind games, narcissists use physical attractiveness, and psychopaths use physical threats. It is stated that all three personality structures have an exploitative, opportunistic and variable attitude in both daily life and business life.

\subsection{Organizational Commitment}

Organizational commitment is an individual's strong belief in the organization's goals and values, an effort to achieve these goals, and a desire to maintain membership in the organization (Swailes, 2002).

Organizational commitment is a term which combines attributes such as protecting organizational values, adopting the goals of the organization, willingness to work for the organization and to continue to work in the organization (Polat \& İskender, 2018).

Organizational commitment is a psychological condition that connects the individual to the organization. It was examined within three dimensions; emotional commitment, normative commitment, and rational commitment (Allen \& Meyer, 1990).

Emotional commitment: The person firmly accepts the values of the organization and works with the basic motivation to be a part of the organization. Emotional commitment involves employee identification with the organization and participation in the organization.

Continuance commitment: If the employee finds his/her career, seniority and benefits from the organization high and does not want to lose them, continuance commitment comes to the fore. Therefore, although the employee is not satisfied, s/he remains at the organization and continues to work (Allen \& Meyer, 1990).

Continuance commitment arises when the idea such as rights, seniority, promotion opportunities, wages they have in the organization is indispensable for the employee or cannot be obtained elsewhere.

Normative commitment shows employees' beliefs about their responsibilities towards their organizations. It is to adopt and internalize all the goals and duties that the organization has specified without question. Employees do this because they think it is completely ethical and correct (Duma \& Eren, 2005)

Normative commitment occurs when employees commit because of a moral obligation to stay in the organisation and employees feel that they must stay in the organisation (Dunham, Grube, \& Castaneda, 1994).

\section{Methodology}

\subsection{Research Goal}

This study aimed to investigate the relationships between dark triad traits and organizational commitment dimensions of academics who work for Faculty of Sport Sciences. Accordingly, the research is an example of the relational survey model. Correlational studies, also called relational research, examine the relationship between two or more variables or data sets (Fraenkel \& Wallen, 2009).

\subsection{Population and Sample}

The sample of this research consists of 372 volunteers determined by random method among 1680 academics working in the Faculty of Sport Sciences in the academic year 2017-2018. 


\subsection{Data Collection Tools}

Short Dark Triad (SD3): The Short Dark Triad Scale (SD3) developed by Jones and Paulhus (2014) and adapted to Turkish by Agrali-Ermis, Sahin, and Demirus (2018) was used to determine the dark triad traits of academicians.

Dark Triad Scale: It consists of a total of 27 items collected in three dimensions which are Machiavellianism $(\alpha=$ $0.778)$, narcissism $(\alpha=0.730)$ and psychopath $(\alpha=0.710)$.

Organizational Commitment Scale: Organizational Commitment Scale developed by Allen and Meyer (1996) was used to determine the levels of organizational commitment of the academic staff who participated in the study. The scale consists of 18 items collected in three dimensions that are emotional commitment, continuance commitment and normative commitment. The high scores obtained from the scale show that the organizational commitments of the participants towards their organizations are high. This scale was adapted to Turkish by many researchers. In the research on academics working in sports sciences, Cronbach Alpha coefficient was calculated in order to find the reliability levels of the lecturers' answers to the scale items, and it was found to be 0.925 for emotional commitment, 0.675 for continuance commitment, and 0.703 for normative commitment. Cronbach Alpha coefficient for the lecturers' answers to 18 items of the scale was found as 0.801 (Koç, 2018)

In the analysis of the data obtained from the scales, Pearson correlation coefficient was calculated in order to determine the level of relationship.

\section{Findings}

Table 1. Relationships between participants' organizational commitments and dark triad traits

\begin{tabular}{cccccc}
\hline Commitment & Values & Machiavellianism & Narcissism & Psychopath \\
\hline \multirow{2}{*}{ Organizational commitment } & $\mathrm{r}$ & 0.088 & 0.063 & 0.078 \\
& $\mathrm{p}$ & 0.211 & 0.353 & 0.240 \\
& $\mathrm{~N}$ & 372 & 372 & 372 \\
\hline
\end{tabular}

$* \mathrm{p}<0.05 ; * * \mathrm{p}<0.01$

When the information in the table is examined, it was determined that there was no significant relationship between the organizational commitments of the academics working in the faculty of sports sciences and Machiavellianism personality traits $(r=0.088 ; p>0.05)$, narcissism personality traits $(r=0.063 ; p>0.05)$ and psychopathy personality traits $(r=0.078 ; \mathrm{p}>0.05)$.

Table 2. Relationships between participants' emotional commitments and dark triad traits

\begin{tabular}{cccccc}
\hline Commitment & Values & Machiavellianism & Narcissism & Psychopath \\
\hline \multirow{3}{*}{ Emotional commitment } & $\mathrm{r}$ & -.131 & .113 & -.141 \\
& $\mathrm{p}$ & .552 & .798 & .426 \\
& $\mathrm{~N}$ & 372 & 372 & 372 \\
\hline
\end{tabular}

$* \mathrm{p}<0.05 ; * \mathrm{p}<0.01$

When the information in the Schedule examined, a very low level of inverse correlation was determined between the emotional commitments of the academics participating in the study and the personality traits of Machiavellianism $(r=-0.113 ; p>0.05)$ and psychopathy personality traits $(r=-0.141 ; p>0.05)$.

Table 3. Relationships between participants' continuance commitments and dark triad traits

\begin{tabular}{ccccc}
\hline Commitment & Values & Machiavellianism & Narcissism & Psychopath \\
\hline & $\mathrm{r}$ & $0.396^{* *}$ & $0.174^{* *}$ & $0.322^{* *}$ \\
Continuance commitment & $\mathrm{p}$ & 0.000 & 0.003 & 0.000 \\
& $\mathrm{~N}$ & 372 & 372 & 372 \\
\hline
\end{tabular}

$* \mathrm{p}<0.05 ; * \mathrm{p}<0.01$.

Looking at Table 3, it is observed that there is a moderate positive difference between the continuance commitment 
of academics and the personality traits of Machiavellianism $(\mathrm{r}=0.396 ; \mathrm{p}<0.01)$ and psychopathy $(\mathrm{r}=0.32 ; \mathrm{p}<$ $0.05)$, and a very low level of relationship between it and narcissism $(r=0.194 ; p>0.05)$ personality traits.

Table 4. Relationships between participants' normative commitments and dark triad traits

\begin{tabular}{cccccc}
\hline Commitment & Values & Machiavellianism & Narcissism & Psychopath \\
\hline \multirow{3}{*}{ Normative commitment } & $\mathrm{r}$ & 0.009 & -0.009 & 0.039 \\
& $\mathrm{p}$ & 0.857 & 0.856 & 0.455 \\
& $\mathrm{~N}$ & 372 & 372 & 372 \\
\hline
\end{tabular}

$* \mathrm{p}<0.05 ; * * \mathrm{p}<0.01$

According to Table 4, no significant relationships were found between the normative commitments of the participants and Machiavellianism personality traits $(r=0.009 ; \mathrm{p}>0.05)$, narcissism personality traits $(\mathrm{r}=-0.009$; $\mathrm{p}>0.05)$ and psychopathy personality traits $(\mathrm{r}=0.039 ; \mathrm{p}>0.05)$.

\section{Discussion}

The analysis of the relationship between academics' dark triad personality traits and organizational commitment dimensions was interpreted and discussed on the basis of the literature.

Considering the correlation results, no statistically significant relationship was found between the overall organizational commitment of academics and dark triad traits. In other words, when the three components that make up the organizational commitment are analysed together, the relationship with the dark triad traits was not significant.

However, in several studies in the related literature, they predict three important categories as personal characteristics, work-related factors and professional participation factors as premises that affect organizational commitment (Steers, 1977; Mathieu \& Zajac, 1990; Joiner \& Bakalis, 2006). In addition, Becker and O'Hair (2007) found a negative association between Machiavellianism and citizenship behaviour.

However, there are different results in the literature; they found no relationship between Machiavellianism, subclinical narcissism and citizenship behaviour, and our findings suggest only a weak association between the two constructs (Schütte et al, 2018: Szabó, Czibor, Restás, \& Bereczkei, 2018).

When the data for the correlation analysis obtained from the research are analysed in detail according to the sub-dimensions, a very low level of inverse correlation was determined between the emotional commitments of academics and the personality traits of Machiavellianism $(r=-0.113 ; p>0.05)$ and psychopathy personality traits $(\mathrm{r}=-0.141 ; \mathrm{p}>0.05)$.

When the studies on the relationship of Machiavelist, narcissistic and subclinical psychopathic traits, which are included in the personal traits, with the organizational commitment in the related literature are examined, it is observed that while result obtained by Ying and Cohen (2018) that narcissism reduces the emotional commitment which is among the sub-factors of organizational commitment differentiates with this research, the fact that no significant relationship between narcissistic personality traits and organizational commitment behaviours was found in the studies of Cihangiroğlu, Teke, Uzuntarla, and Ugrak (2015) supports research results.

However, the fact that Becker and Dan O'Hair (2007) determined the negative effect of Machiavellianism, one of the dark triad traits, in organizational commitment stages and that Özsoy, Ardıç, \& Balaban (2017) did not find a relationship between the level of narcissism of participants and organizational commitment, but found a negative relationship between the Machiavellian and psychopathy traits and the organizational commitment is partly in line with the findings of the study.

It was determined that there is a moderate positive relationship between the continuance commitment, which is another organizational commitment sub-dimension, and Machiavellianism $(r=0.396 ; p<0.01)$ and Psychopathy $(\mathrm{r}=0.32 ; \mathrm{p}<0.05)$ personality traits, but a very low level of relationship was found between it and narcissism $(\mathrm{r}=$ $0.174 ; p>0.05)$ personality traits. In other words, as the continuance commitment that indicates the need of academic staff to stay in the organization increases, their levels of Machiavelist traits and psychopathy traits that are expressed as the desire to satisfy their own wishes and needs in order to maintain personal power in organizational environment increase.

According to Sarker et al. (2013), with the reflection of personality on the levels of social interaction among individuals, it is expected to affect the attitudes and behaviors of the employees towards their colleagues and the 
organization. Especially in organizations providing services, the fact that employees directly affect service processes and organizational outputs makes personality traits even more important (Kanten, Yeşiltaş, \& Aslan, 2015).

In the study, it was determined that there was no significant relationship between normative commitment and Machiavelist personality, narcissistic personality traits and psychopathic personality traits. Mathieu, Neumann, Hare, and Babiak (2014) observed, in their study, a decrease in the normative commitments of individuals with a Dark triad-like attitude, which differs from the results of the current research.

Similarly, Sanecka (2013), another researcher, also revealed that subclinical psychopathy has a negative effect on the organizational commitment and the normative and emotional commitment, which are the sub-dimensions of organizational commitment, especially in individuals who have undertaken managerial duties. Based on these points, it is believed that increasing the ethical quality of people's behaviour, giving more places to correct, fair and egalitarian practices, and acting as individual with conscience and empathy are also considered to increase organizational commitment.

As a result, according to the correlation results obtained from the research, no statistically significant relationship was found between the overall organizational commitment and dark triad traits. While a very low level of inverse correlation was determined between the emotional commitments of academics and the personality traits of Machiavellianism and psychopathy, a moderate direct level of relationship was found between the continuance commitment and the personality traits of Machiavellianism and psychopathy.

When the findings obtained from the correlation analysis of the research are evaluated in general, similar and different research results are seen in the related literature. However, considering the low number of studies on the subject in the literature, it can be said that making a general inference based on these findings is not very accurate. Moving from this point, as the amount of primary data obtained by studies from different samples increases, the effect of dark triad traits on organizational behaviour will be more clearly revealed.

In addition, studies should be conducted in different dimensions of organizational behaviours (organizational justice, organizational burnout, job satisfaction, and organizational loneliness) to reveal the effect of Dark triad traits on organizational behaviour more clearly.

\section{References}

Agrali-Ermis, S., Sahin, M. Y., \& Demirus, B. (2018). The Adaptation of Short Dark Triad (SD3) Inventory to the Turkish sample: The study of validity and reliability. JRES, 5(2), 138-156.

Allen, N. J., \& Meyer, J. P. (1996). Affective, continuance, and normative commitment to the organization: An examination of construct validity. Journal of Vocational Behavior, 49(3), 252-276. https://doi.org/10.1006/jvbe.1996.0043

Allen, N. J., \& Meyer, J. P. (1990). The measurement and antecedents of affective, continuance and normative commitment to the organization. Journal of Occupational Psychology, 63, 1-18. https://doi.org/10.1111/j.2044-8325.1990.tb00506.x

Arrigo, B. A., \& Shipley, S. (2001). The confusion over psychopathy (I): Historical considerations. International Journal of Offender Therapy and Comparative Criminology, 45(3), 325-344. https://doi.org/10.1177/0306624X01453005

Becker, J. A. H., \& O'Hair, H. (2007). Machiavellians' motives in organizational citizenship behavior. Journal of Applied Communication Research, 35(3), 246-267. https://doi.org/10.1080/00909880701434232

Cihangiroğlu, N., Teke, A., Uzuntarla, Y., \& Uğrak, U. (2015). Analysis of The Relationship Between Narcissistic Personality Trends and Organizational Commitment Levels. Journal of Management and Economics Research, 13(1), 1-18.

Duma, U., \& Eren, V. (2005). The Examination of Organisational Commitment in Connection With Three Components of Commitment. Doguş University Journal, 6(2), 211.

Dunham, R. B., Grube, J. A., \& Castaneda, M. B. (1994). Organizational commitment: The utility of an $\begin{array}{llll}\text { integrative definition. Journal of Applied Psychology, 79(3), 370-380. } & \text {. }\end{array}$ https://doi.org/10.1037/0021-9010.79.3.370

Fehr, B., Samson, D., \& Paulhus, D. L. (1992). The construct of Machiavellianism: Twenty years later. In C. D. Spielberger, \& J. N. Butcher (Eds.), Advances in personality assessment (Vol. 9, pp. 77-116). Hillsdale, NJ, US: Lawrence Erlbaum Associates, Inc. 
Fraenkel, J. R., \& Wallen, N. E. (2009). How To Design And Evaluate Research In Education (7th ed.). New York: McGraw-Hill.

Geçtan, E. (2010). Psikodinamik psikiyatri ve normal dişi davranişlar. İstanbul: Metis Yayinlari.

Joiner, T. A., \& Bakalis, S. (2006). The antecedents of organizational commitment: the case of Australian casual academics. International Journal of Educational Management, 20(6), 439-452. https://doi.org/10.1108/09513540610683694

Jonason, P. K., Slomski, S., \& Partyka, J. (2012). The Dark Triad at work: How toxic employees get their way. Personality and Individual Differences, 52(3), 449-453. https://doi.org/10.1016/j.paid.2011.11.008

Jonason, P. K., Wee, S., Li, N. P., \& Jackson, C., (2015). Occupational niches and the dark triad traits. Personality and Individual Differences, 69, 112-123. https://doi.org/10.1016/j.paid.2014.05.024

Jones, D. N., \& Paulhus, D. L. (2014), Introducing the short dark triad (SD3): A brief measure of dark personality traits. Sage Pub Assessment, 21(1), 28-41. https://doi.org/10.1177/1073191113514105

Judge, T. A., \& LePine, J. A. (2007). The bright and dark sides of personality: Implications for personnel selection in individual and team contexts. In J. Langan-Fox, C. L. Cooper, \& R. J. Klimoski (Eds.), New horizons in management. Research companion to the dysfunctional workplace: Management challenges and symptoms (pp. 332-355). Edward Elgar Publishing. https://doi.org/10.4337/9781847207081.00028

Kanten, P., Yeşiltaş, M., \& Arslan, R. (2015). The Moderating Role of Psychological Contract in the Effect of Dark Side of Personality on Counterproductive Work Behavior. Ataturk University Journal of Economics and Administrative Sciences, 29(2), 365-391.

Koç, M. (2018). Research on correlations between academicians' levels of organisational commitment and their intention to quit their job: A comparison of state and foundation universities. Journal of Education and Learning, 7(1), 163-173. http://doi.org/10.5539/jel.v7n1p163

Mathieu, J. E., \& Zajac, D. M. (1990). A review and meta-analysis of the antecedents, correlates and consequences of organizational commitment. Psychological Bulletin, 108(2), 171-186. https://doi.org/10.1037/0033-2909.108.2.171

Mathieu, C., Neumann, C. S., Hare, R. D., \& Babiak, P. (2014). A dark side of leadership: Corporate psychopathy and its influence on employee well-being and job satisfaction. Personality and Individual Differences, 59, 83-88. https://doi.org/10.1016/j.paid.2013.11.010

Özsoy, E., Ardiç, K., \& Balaban, Ö. (2017). Examining the Effects of Dark Triad on Organizational Commitment. International Congress on Politic, Economic and Social Studies. Ankara.

Paulhus, D. L., \& Williams, K. M. (2002). The dark triad of personality: Narcissism, machiavellianism, and psychopathy. Journal of Research in Personality, 36, 556-563. https://doi.org/10.1016/S0092-6566(02)00505-6

Polat, D. D., \& İskender, M. (2018). Exploring Teachers' Resilience in Relation to Job Satisfaction, Burnout, Organizational Commitment and Perception of Organizational Climate. International Journal of Psychology and Educational Studies, 5(3), 1-13. https://doi.org/10.17220/ijpes.2018.03.001

Sanecka, E. (2013). Perceived supervisor's subclinical psychopathy, and subordinate's organizational commitment, job satisfaction and satisfaction with executive. Journal of Education Culture and Society, 2, 172-191. https://doi.org/10.15503/jecs20132.172.191

Sarker, S., Bose, T. K., Palit, M., \& Haque, E. (2013). Influence of personality in buying consumer goods-a comparative study between neo-Freudian theories and trait theory based on Khulna region. International Journal of Business and Economics Research, 2(3), 41-58. https://doi.org/10.11648/j.ijber.20130203.12

Schütte, N., Blickle, G., Friedler, R. E., Wihler, A., Schnitzler, F., Heupel, J., \& Zettler, I. (2018). The role of interpersonal influence in counterbalancing psychopathic personality trait facets at work. Journal of Management, 44(4), 1338-1368. https://doi.org/10.1177/0149206315607967

Steers, R. M. (1977). Antecedents and outcomes of organizational commitment. Administrative Science Quarterly, 22, 46-56. https://doi.org/10.2307/2391745

Swailes, S. (2002). Organizational commitment: a critique of the construct and measures. International Journal of Management Reviews, 4(2), 155-178. https://doi.org/10.1111/1468-2370.00082

Szabó, Z. P., Czibor, A., Restás, P., \& Bereczkei, T. (2018). “The Darkest of all” The relationship between the 
Dark Triad traits and organizational citizenship behavior. Personality and Individual Differences, 134, 352-356. https://doi.org/10.1016/j.paid.2018.04.026

Ying, L., \& Cohen, A. (2018). Dark triad personalities and counterproductive work behaviors among physicians in China. The International Journal of Health Planning and Management, 33(4), 985-998. https://doi.org/10.1002/hpm.2577

\section{Copyrights}

Copyright for this article is retained by the author(s), with first publication rights granted to the journal.

This is an open-access article distributed under the terms and conditions of the Creative Commons Attribution license (http://creativecommons.org/licenses/by/4.0/). 